\title{
Shallow Depth Soil Resistivity Investigations and Subsurface Lithology for Corrosivity Assessment along Obama-Kolo Creek Pipeline Using Geoelectric Method
}

\author{
Amechi, Bright $\mathrm{U}^{1} \&$ Opiriyabo I. Horsfall ${ }^{2 *}$ \\ ${ }^{I}$ Department of Geology, Rivers State University, Port Harcourt, Nigeria. \\ ${ }^{2}$ Department of Physics, Rivers State University, Port Harcourt, Nigeria. \\ *Corresponding Author: O. I. Horsfall, Department of Physics, Rivers State University, P.M.B 5080, Port Harcourt, Nigeria. \\ *Email: opiribenibo@yahoo.com,horsfall.opiriyabo@ust.edu.ng,uka.livinus@yahoo.com
}

\section{ABSTRACT}

\begin{abstract}
Corrosion is a mechanism that degrades materials and causes structural failures in infrastructures, which can lead to severe effects on the environment and have direct impact on the population health. In addition, corrosion is extremely complex in the underground environment due to the variability of the local conditions. The delineation and assessment of possible areas of corrosion along Obama-Kolo Creek, in the Niger Delta region was carried out using Earth resistivity measurement. The aim of this study is to evaluate the influence of soil resistivity upon metals buried underground. In this investigation, an Abem SAS 300B meter was used and 20 sounding points were carried out using the Schlumberger array along the pipeline route. A total spread $(\mathrm{AB})$ of $45 \mathrm{~m}$ was adopted with the assumption that the depth of penetration is $\frac{1}{r}$ th of the total current electrode spread (AB). The results obtained showed that subsoil resistivity values for depths of $2-12 \mathrm{~m}$ required for the underground pipe laying with resistivities in the range of 8 Ohm-m to $78 \mathrm{Ohm}-\mathrm{m}$ along Obama - Kolo Creek with a mean of $43 \mathrm{Ohm}-\mathrm{m}$. The low resistivity encountered throughout the study has been attributed to the influence of saline water intrusion in the area. The average thickness of this area is $7 \mathrm{~m}$. Basically, most of the geoelectric graphs showed three layers, H-type curves. Generally, the subsurface soil is made up of subsoil lithology of mainly clayey/sandy clay material with differen degree of saturation. This is an indication that any underground metallic material will be exposed to high corrosivity environment, hence appropriate cathodic protection will be required.
\end{abstract}

Keywords: Lithology, Geoelectric, Corrosivity, Cathodic, Resistivity.

\section{INTRODUCTION}

Soil resistivity influences the corrosion of metals installed underground and can serve as an indicator of soil corrosiveness. From corrosion engineering perspective, the lower the resistivity, the higher the corrosivity and vice versa. Soil resistivity is most often measured using either Schlumberger or Wenner four-electrode method and resistance meter. The aim of this study is to evaluate the influence of soil resistivity upon metals buried underground. The resistivity of the soil is a measure of the resistance offered by soil in the flow of electricity. The soil resistivity depends on a number of factors such as soil composition, moisture, temperature, etc. Generally, the soil is not a homogeneous and their resistivities varies with depth. Soil is a critical factor in the design of ground (earthing) and cathodic protection system for pipe laying.

Actual resistivity measurements are required to fully qualify the resistivity and its effects on the overall transmission system and corrosion of buried metals. [8] basically, soil resistivity tests measure the electrical conductivity of the soil to allow for the creation of an electrical equivalent soil model that can be used in earthing and corrosion design software. Corrosion is the gradual chemical attack and degradation that results in the corrosion of metallic materials into oxides, salts or other compounds.

Materials such as metals and its alloys (e.g. steel) that have undergone corrosion lose their strength, ductility and mechanical properties. Structures such as natural gas and crude oil pipeline and water pipes are some of the structures reported to have been affected by soil corrosion all around the world [3]. Coastal soils are usually prone to pollution and corrosion by seawater due to large number of dissolved solutes (anions and cations) in seawater. 
Vertical electrical soundings (VES) using the Schlumberger (or Wenner) arrays with spacing up to 100m or more where necessary is effective and suitable in evaluating the degree of soil aggressiveness [3,7]. Corrosion increases as resistivity decreases. Prime factors that affect soil electrical resistivity, the severity and acceleration of corrosion of metals in soil include moisture content, salts (particularly sulphide and chloride) content, acid content and aeration. Each factor has an effect on soil electrical resistivity. Soil resistivity is typically indicative of soil corrosivity in alkaline soils and is useful as a guide in acid soils. Therefore, for durable engineering structures and pipeline laying, it is pertinent to estimate the degree of soil corrosivity/aggressivity prior to construction works [7] In view of the above, the study was carried out to determine the corrosivity and subsurface lithology along Kolo Creek - Obama pipeline using Geoelectric method in the Niger Delta Region of Nigeria to delineate potential corrosive zones

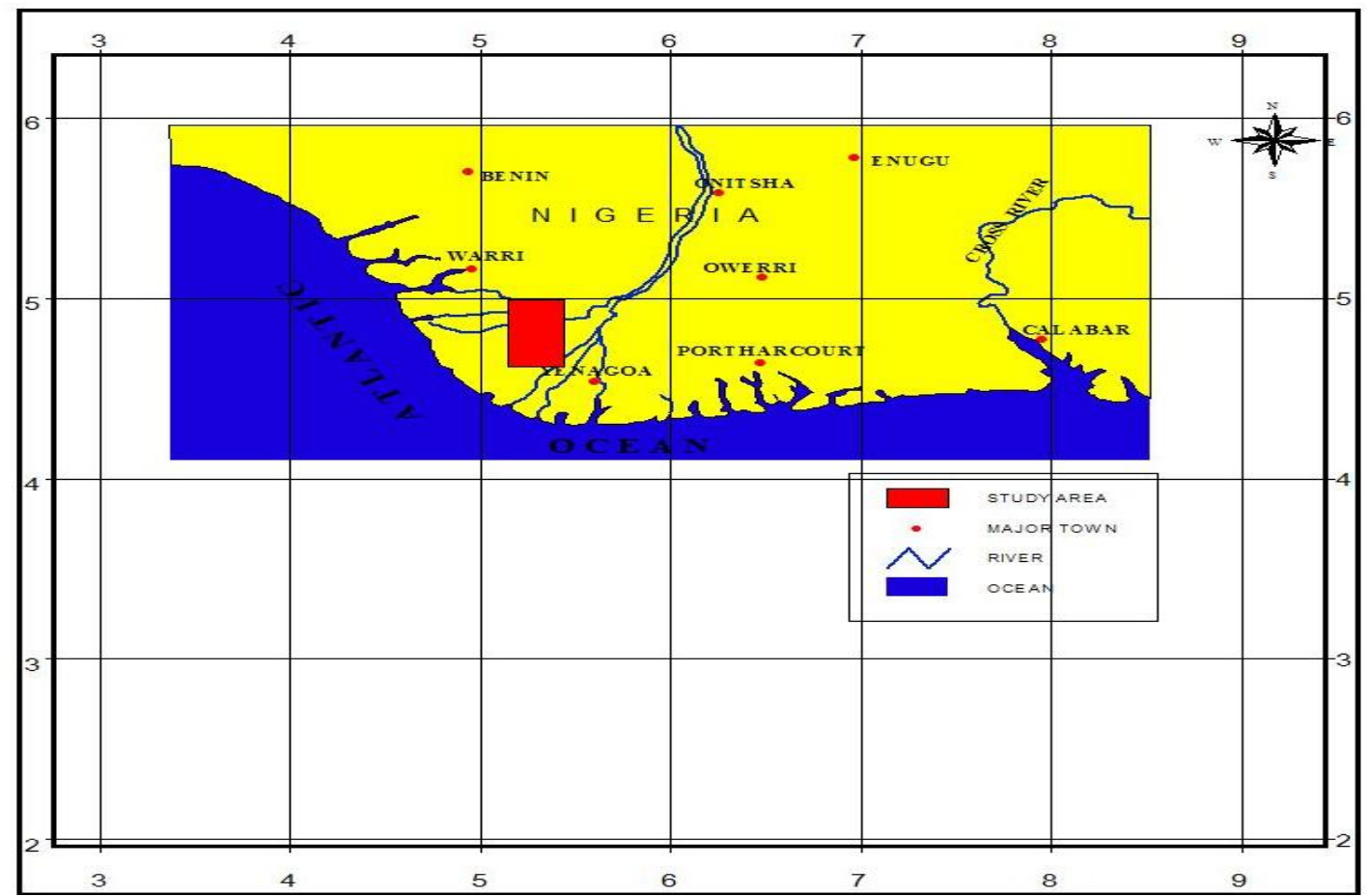

Fig 1. Base map showing the study area.

\section{Geology and Hydrogeology of the area}

The study area is part of the Niger Delta complex which generally indicates beds of fine to coarse sand typical of fluvial channel deposits. The area is composed of mainly two distinct lithological formations Quaternary, Deltaic plain (upper and lower) and Tertiary, Benin and Ameki formations. The Deltaic plain is made up of units consisting of coarse to medium grained unconsolidated sands, forming lenticular beds with intercalations of peaty matter and lenses of soft, silt clay and shale. The lower most (Akata formation) is composed of uniform shale grading upwards to grey sandy silt shale. [4]. It often contains sandstone lenses near the contact with the overlying (Agbada formation) and attains a minimum thickness of $1200 \mathrm{~m}$. The Agbada formation consists of upper predominantly sandy unit, minor shale intercalations and a lower unit which is thicker than the upper sandy unit. The sandy beds of the formation form prolific aquifers. The high permeability of the Benin formation, the overlying lateritic red earth 
and weathered top of the formation as well as the underlying clay-shale member of the Bende-Ameki and Ogwashi-Asaba series provide the hydrologic conditions favoring aquifer formation in the area.

Gravelly beds up to $9 \mathrm{~m}$ thick were reported by [4] The top sediments are aerated unconsolidated sandstones and have a highly variable thickness throughout the region. This formation consists of sands, clay, lignite, peat and some granular gravel. The clay strata in this formation are of varying thickness ranging from $3 \mathrm{~m}$ to $10 \mathrm{~m}$. The sands and sandstone are coarse grained, gravelly and locally fine grained. They range in colour from white to yellowish brown. The high yielding permeability of the Benin formation, the overlying lateritic red earth and weathered top of the formation as well as the underlying clay - shale member of the Bende-Ameki series provide the hydrologic conditions favoring aquifer formation in the area.

However, the aquifers in this area obtain recharge by precipitation mainly from rainfall. The potential sources of drainage include rivers and streams that crisscrossed the area. The depth to water table in the Benin formation ranges from $3 \mathrm{~m}$ to $15 \mathrm{~m}$ below ground level [6].

Generally, the sediments in the Niger Delta range in age from Paleocene to recent. Due to the more prolific character of Benin formation, their aquifers are expected to discharge more copiously than the Deltaic sediments. Moreover, with little run-off and other loses much of the water will go into storage. Nevertheless, the aquifers at shallow depths $(10 \mathrm{~m})$ are unconfined while the deeper aquifers are confined and isolated from the ground surface. The water expected from the shallow layers are generally of low $\mathrm{P}^{\mathrm{H}}$ value (acidic) and high carbon dioxide. These waters are highly corrosive and soft. Besides, these waters contain high dissolved iron and needs treatment. The upper unconfined aquifer varies from $15 \mathrm{~m}$ to nearly $100 \mathrm{~m}$. The middle semi- confined aquifer consists of medium to coarse grained sands with clay lenses and fine clayey sands. This section ranges between $100 \mathrm{~m}$ to $200 \mathrm{~m}$. The confined aquifer extends from $200 \mathrm{~m}$ to $300 \mathrm{~m}$ depths and consists of coarse-grained sands and grained with some clay intercalates. [6]. Generally fresh water is expected from this aquifer.

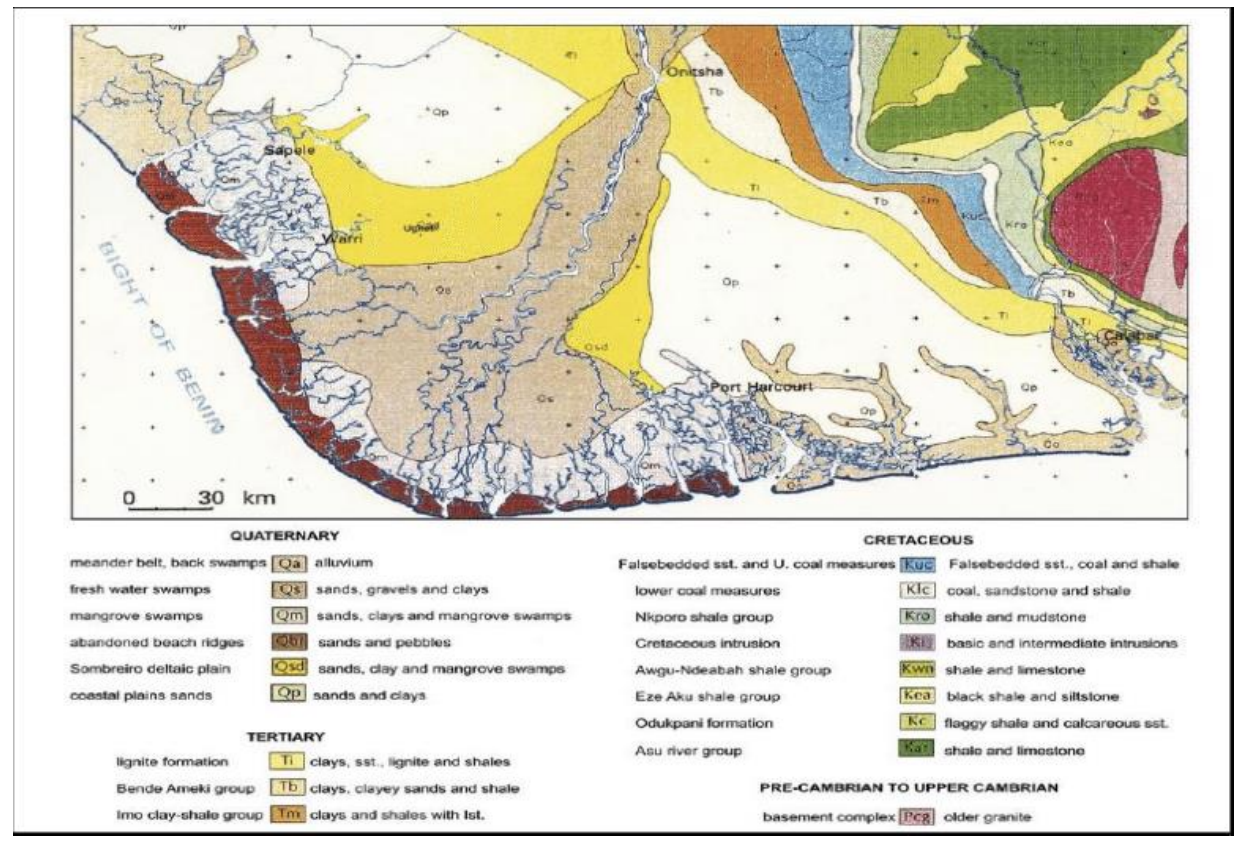

Fig 2. Geological map of the Niger Delta and surroundings [10] 


\section{Climate and vegetation of the study area}

The climate of the study area is tropical and dominated by two main seasons: the dry and rainy seasons. Total rainfall per annum: is over $2400 \mathrm{~mm}$ and according to hydro-geological studies over $40 \%$ of this infiltrate and recharge groundwater [4]. The soil profile is remarkably uniform throughout the area. Approximately, the whole areas consist of deeply weathered and intensely leached soil. The heavy rainfall coupled with the drainage nature of the sub soil is conducive for the high infiltration of rain water. The proximity of Nigeria to the equator is responsible for the general high temperature. A mean temperature of $27^{\circ} \mathrm{C}$ is recorded in part of the Niger Delta Region. Minimum temperatures in the coastal states are highest in February, March and April and lowest in January and August. Relative humidity near the coast is about $80 \%$ to $1000 \%$ at down and 70 to $80 \%$ in early afternoon at maximum temperature.[6].

The vegetation cover is thick mangrove in a very swampy environment implying significant evapo-transpiration effect. Run-off is completely limited following the thick vegetation; hence ground water recharge and storage in plentiful in this area. However, the water table is deep $(>3 \mathrm{~m})$, hence chances of groundwater ex-filtration and evaporation is low. Generally speaking, the vegetation of the Benin formation is flat lying with the greatest height not exceeding 180m above sea level. The ground level however, slopes gently towards the Niger River flood plains, being directed mainly by the Cross, Imo, Kwaibo and Sombreiro River systems. The vegetation is typically tropical rain forest.

\section{Basic theory of resistivity and soil corrosivity}

The electrical resistivity (or specific resistance) of a medium is the resistance offered by a unit cube of it when a unit current passes normal to the surface of a cross - sectional area. It is given by Ohm's law

$$
\rho=\frac{R A}{L}
$$

where $\rho=$ resistivity, $R=$ resistance offered by the medium of length $L$ and cross-sectional area, $A$. In electrical resistivity survey, a known current I (direct current or law frequency alternating current) is sent into the ground through a pair of current electrodes $\mathrm{A}$ and $\mathrm{B}$, and the potential difference $\Delta V$ created in the medium between another pair of potential electrodes $\mathrm{M}$ and $\mathrm{N}$ (fig.3). is measured. The resistivity of the formation is then given by

$$
\rho=K \frac{\Delta V}{L}
$$

where $K$ is termed the geometric factor of the electrode arrangement and it is expressed as

$$
K=\frac{2 \pi}{\frac{1}{A M}-\frac{1}{B M} \frac{1}{A N}+\frac{1}{B N}}
$$

and $A M, B M, A N, B N$ are distances between the designated electrodes. 


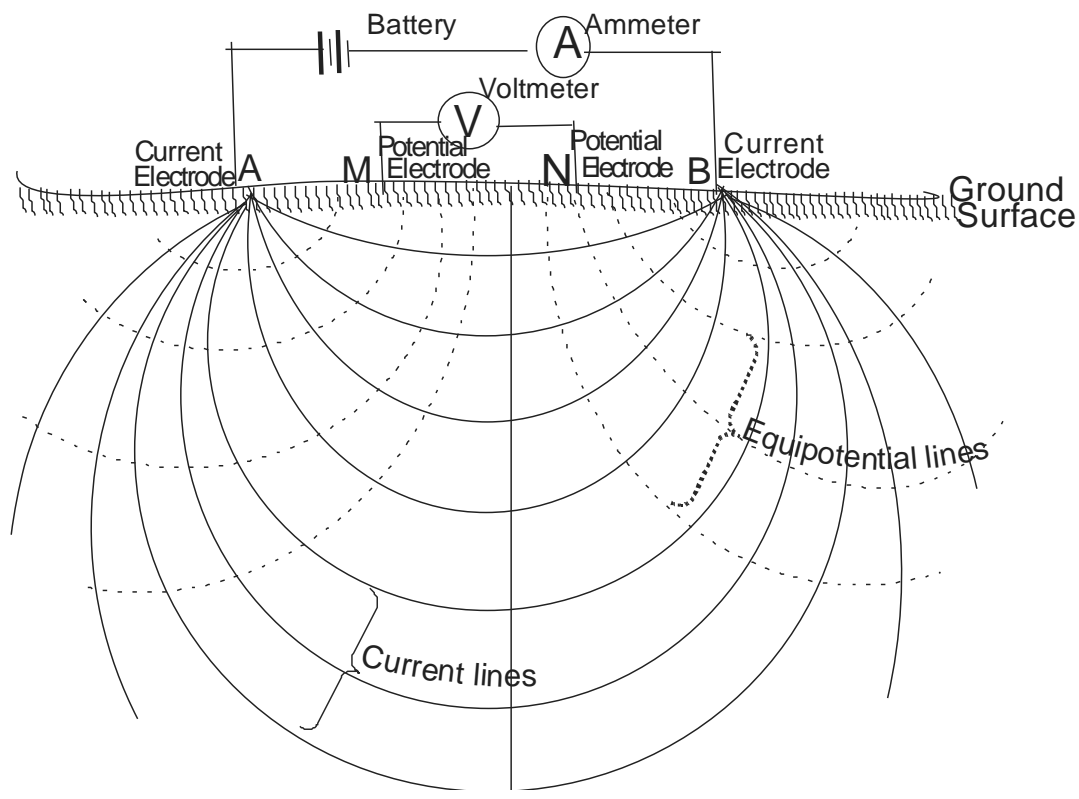

Fig 3. Electrical circuit for resistivity determination an electrical field for a homogeneous datum (after Telford, W.M, 1976)

$\rho$ expressed above represents the true receptivity of the material of the formation which is homogeneous and isotropic in nature, and only the apparent receptivity, $\rho_{\mathrm{a}}$, if the formation is anistropic, consisting of two or more layers of different resistivities [11]. The apparent resistivity values depend on several variables like electrode spacing, geometry of electrode array, true resistivity and other features of underlying formations such as layer thickness, dip and anistropic properties. The apparent resistivity, depending on the electrode configuration and geology may be a crude weighted average of the true resistivities or even negative [9]. The effective depth of current penetration, and hence of the investigation, increases with increase in electrode spacing.

\section{Procedure for Field data Collection}

The electrical resistivity method is commonly used for the delineation of horizontal and vertical discontinuities in the electrical properties of the subsurface and also for the detection of three-dimensional bodies of anomalous electrical conductivity. In the electrical resistivity method, artificially generated currents are introduced into the ground, through Abem SAS 300B terrameter, after all necessary connections and in the presence of variations in the conductivity of subsurface layers, the current flow path is altered which affects the electric potential distribution, and the resulting potential differences are measured at the surface. The potential electrodes separation which is increased in steps is assume to be less than $1 / 5^{\text {th }}$ of the current electrodes' separation, i.e. $\mathrm{P}_{1} \mathrm{P}_{2}<\mathrm{C}_{1} \mathrm{C}_{2} / 5$. A total current electrode separation of $45 \mathrm{~m}$ was marked out in this study. In each measurement, the digital averaging instrument displayed the resistance of the various formations. The measurements for the Schlumberger array commence with $\mathrm{AB}_{2}$ or $\mathrm{C}_{1} \mathrm{C}_{2}=1.5 \mathrm{~m}$ and $\mathrm{MN} / 2 \quad \mathrm{P}_{1} \mathrm{P}_{2}=0.3 \mathrm{~m}$; which was gradually and symmetrically increased in steps complying with the relation $5 \mathrm{MN} / 2<\mathrm{AB} /{ }_{2}$. With this procedure often called electric drilling the properties of the subsurface was explored. [1]

The corrosivity of soils is inversely related to the soil resistivity, with low resistivity indicating high probability of corrosion [5]. The soil resistance is given by $\mathrm{R}=\mathrm{V} / \mathrm{I}$. this needs to be standardized over a unit length. The apparent 
resistivity $\rho_{a}$ measured in ohm-m was obtained from the equation, $\rho_{a}=2 \pi d R$ where, $d$ is spacing between the electrodes

\section{Discussions - Analysis and Results}

Table 1. Results of the sample sounding points indicating the layer resistivities and thicknesses

\begin{tabular}{|c|c|c|c|c|c|c|c|c|c|}
\hline $\begin{array}{c}\text { VES } \\
\text { POINT }\end{array}$ & $\begin{array}{l}\text { No of } \\
\text { layers }\end{array}$ & $\begin{array}{c}\text { Layer } \\
\text { Resistivity } \\
\text { (Ohm-m) }\end{array}$ & $\begin{array}{c}\text { Layer } \\
\text { thickness } \\
\text { (m) }\end{array}$ & $\begin{array}{c}\text { Depth } \\
\text { (m) }\end{array}$ & $\begin{array}{c}\text { VES } \\
\text { POINT }\end{array}$ & $\begin{array}{l}\text { No of } \\
\text { layers }\end{array}$ & $\begin{array}{c}\text { Layer } \\
\text { Resistivity } \\
\text { (Ohm-m) }\end{array}$ & $\begin{array}{c}\text { Layer } \\
\text { thickness } \\
\text { (m) }\end{array}$ & $\begin{array}{c}\text { Depth } \\
\text { (m) }\end{array}$ \\
\hline 1 & $\begin{array}{l}1 \\
2\end{array}$ & $\begin{array}{l}356 \\
24\end{array}$ & $\begin{array}{l}2.5 \\
7.4\end{array}$ & $\begin{array}{l}2.5 \\
9.9\end{array}$ & 11 & $\begin{array}{l}1 \\
2\end{array}$ & $\begin{array}{c}156 \\
27.9\end{array}$ & $\begin{array}{l}1.76 \\
9.03\end{array}$ & $\begin{array}{l}1.76 \\
10.5\end{array}$ \\
\hline 2 & $\begin{array}{l}1 \\
2\end{array}$ & $\begin{array}{l}197 \\
14.9\end{array}$ & $\begin{array}{l}2.22 \\
3.84\end{array}$ & $\begin{array}{l}2.22 \\
6.09\end{array}$ & 12 & $\begin{array}{l}1 \\
2\end{array}$ & $\begin{array}{l}132 \\
19.4\end{array}$ & $\begin{array}{l}0.75 \\
6.43\end{array}$ & $\begin{array}{l}0.75 \\
7.18\end{array}$ \\
\hline 3 & $\begin{array}{l}1 \\
2\end{array}$ & $\begin{array}{c}197 \\
72.2\end{array}$ & $\begin{array}{l}0.97 \\
10.5\end{array}$ & $\begin{array}{l}0.97 \\
11.5\end{array}$ & 13 & $\begin{array}{l}1 \\
2\end{array}$ & $\begin{array}{l}94.5 \\
13.9\end{array}$ & $\begin{array}{l}1.19 \\
3.84\end{array}$ & $\begin{array}{l}1.19 \\
5.04\end{array}$ \\
\hline 4 & $\begin{array}{l}1 \\
2\end{array}$ & $\begin{array}{l}127 \\
22\end{array}$ & $\begin{array}{l}1.06 \\
5.8\end{array}$ & $\begin{array}{l}1.06 \\
6.86\end{array}$ & 14 & $\begin{array}{l}1 \\
2\end{array}$ & $\begin{array}{c}138 \\
29.2\end{array}$ & $\begin{array}{l}1.30 \\
4.66\end{array}$ & $\begin{array}{l}1.30 \\
5.96\end{array}$ \\
\hline 5 & $\begin{array}{l}1 \\
2\end{array}$ & $\begin{array}{l}127 \\
5.86\end{array}$ & $\begin{array}{l}1.96 \\
3.36\end{array}$ & $\begin{array}{l}1.96 \\
5.32\end{array}$ & 15 & $\begin{array}{l}1 \\
2\end{array}$ & $\begin{array}{l}253 \\
26.4\end{array}$ & $\begin{array}{l}1.12 \\
5.78\end{array}$ & $\begin{array}{c}1.12 \\
6.9\end{array}$ \\
\hline 6 & $\begin{array}{l}1 \\
2\end{array}$ & $\begin{array}{r}133 \\
9.24\end{array}$ & $\begin{array}{l}1.07 \\
9.18\end{array}$ & $\begin{array}{l}1.07 \\
10.2\end{array}$ & 16 & $\begin{array}{l}1 \\
2\end{array}$ & $\begin{array}{l}205 \\
23.2\end{array}$ & $\begin{array}{l}1.02 \\
5.89\end{array}$ & $\begin{array}{l}1.02 \\
6.9\end{array}$ \\
\hline 7 & $\begin{array}{l}1 \\
2\end{array}$ & $\begin{array}{l}184 \\
29.4\end{array}$ & $\begin{array}{l}1.26 \\
4.15\end{array}$ & $\begin{array}{l}1.26 \\
5.41\end{array}$ & 17 & $\begin{array}{l}1 \\
2\end{array}$ & $\begin{array}{l}252 \\
28.8\end{array}$ & $\begin{array}{l}0.98 \\
7.04\end{array}$ & $\begin{array}{l}0.98 \\
8.01\end{array}$ \\
\hline 8 & $\begin{array}{l}1 \\
2\end{array}$ & $\begin{array}{c}197 \\
21.9\end{array}$ & $\begin{array}{l}1.87 \\
2.77\end{array}$ & $\begin{array}{l}1.87 \\
4.58\end{array}$ & 18 & $\begin{array}{l}1 \\
2\end{array}$ & $\begin{array}{l}209 \\
20\end{array}$ & $\begin{array}{l}0.89 \\
8.99\end{array}$ & $\begin{array}{l}0.89 \\
9.88\end{array}$ \\
\hline 9 & $\begin{array}{l}1 \\
2\end{array}$ & $\begin{array}{l}290 \\
58.8\end{array}$ & $\begin{array}{l}1.52 \\
10.5\end{array}$ & $\begin{array}{l}1.52 \\
12.1\end{array}$ & 19 & $\begin{array}{l}1 \\
2\end{array}$ & $\begin{array}{l}41.4 \\
8.88\end{array}$ & $\begin{array}{l}1.07 \\
1.61\end{array}$ & $\begin{array}{l}1.07 \\
2.67\end{array}$ \\
\hline 10 & $\begin{array}{l}1 \\
2 \\
3\end{array}$ & $\begin{array}{c}149 \\
615 \\
28\end{array}$ & $\begin{array}{l}0.86 \\
1.62 \\
3.67\end{array}$ & $\begin{array}{l}0.86 \\
2.47 \\
6.14\end{array}$ & 20 & $\begin{array}{l}1 \\
2\end{array}$ & $\begin{array}{c}78 \\
9.26\end{array}$ & $\begin{array}{l}1.21 \\
2.59\end{array}$ & $\begin{array}{l}1.21 \\
3.8\end{array}$ \\
\hline
\end{tabular}


The apparent resistivity values obtained from the field data were plotted against half current electrodes spacing on a $\log -\log$ scale using a 1D resistivity software. The initial values of the thickness and resistivities of the geoelectric layers encountered within the depth of investigations were obtained. These values were used as the initial model parameters in a computer aided - modeling techniques for invasion algorithms to obtain a final fit to the field data. Few samples of layers parameters (True Resistivity \& Thickness) obtained from the quantitative interpretation are shown in the Figs 4 below. These parameters are therefore, integrated with the available geological information to define the geological picture of the study area. The curves depicted mainly H-type (bowl shape), with $\rho^{1}>\rho^{2}<\rho^{3}$ descending arm which indicates resistive top soil underlain by conductive materials of clayey sands. Results of the field models at various sounding points are shown in table 1 below. The results are mainly three case with the third infinite layer. The results also reveal widely irregular variations in resistivity both vertically and laterally, an indication of the very complex depositional environment of the Niger Delta region.
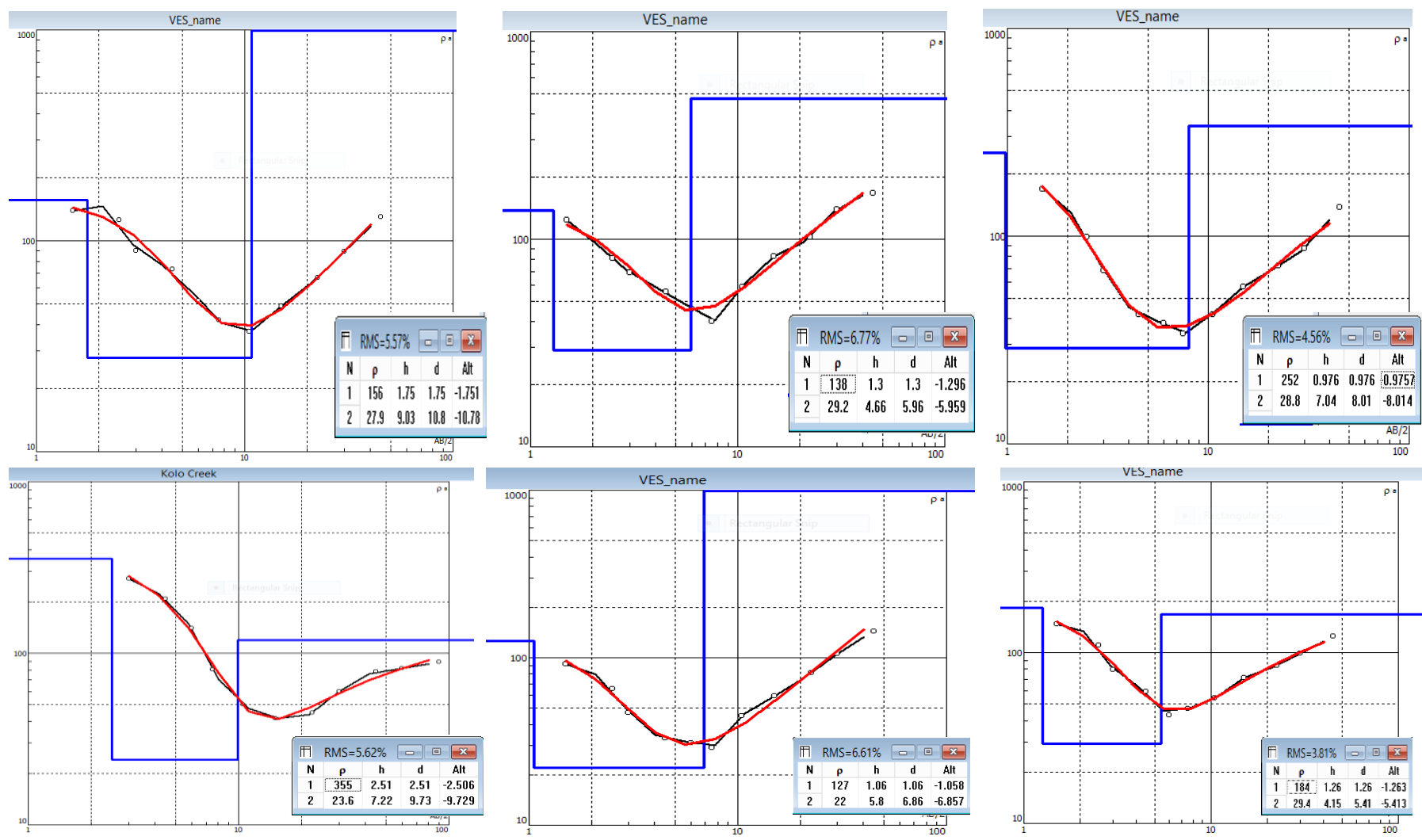

Fig 4. Interpretative sounding curves (H-types)

\section{Soil corrosivity rating along Obama - Kolo Creek Pipeline Route}

The apparent resistivity distribution of the topsoil as obtained from Schlumberger profiles for the selected tested points are presented in Table 1. The variations in the values suggest the general conditions of the surface along the proposed pipeline route. These values show different degree of reworked processes and compaction along the route. Subsoil resistivity values range between $5.86 \mathrm{ohm}-\mathrm{m}$ and $356 \mathrm{ohm}-\mathrm{m}$. These values indicate some degree of corrosion potential of any subsurface piping or structures that would be installed along the proposed pipeline route. The subsoil thickness varies from location to location. The average thickness of this litho-unit is $5.7 \mathrm{~m}$. The curve type is predominantly H-type (Fig.4). Geologically, the subsoil is made up of sandy clayey material with 
preponderance of clayey soil in most cases. Six representative data sheet and layer model interpretation of some points observed along the proposed route are presented in fig. 4. It is important to note that based on the results of the observed points, the entire proposed pipeline route is extremely corrosive.

\section{Evaluation criteria}

For the purposes of evaluating the corrosive electrical properties of the soil with respect to the buried structures, Table $2 \& 3$ was adopted. It must be noted that piping structures installed along the proposed pipeline routes would be subjected to corrosion. The effect is expected to be more severe in areas dominated by mangrove plants because of the influence of saline water.

Table 2. Corrosivity ratings based on soil resistivity according to American Society for Testing and Materials (ASTM G187-12a: Standard Test Method for Measurement of Soil Resistivity Using the Two-Electrode Soil Box Method) and National Association of Corrosion Engineers (NACE).

\begin{tabular}{|c|l|l|}
\hline Soil Resistivity $(\mathbf{\Omega . c m})$ & NACE y Corrosivity Rating & ASTM Corrosivity Rating \\
\hline$>10,000$ & Negligible & Very mildly corrosive \\
\hline $5001-10,000$ & Mildly corrosive & Mildly corrosive \\
\hline $2001-5000$ & Mildly corrosive & Moderately corrosive \\
\hline $1001-2000$ & Moderately corrosive & Severely corrosive \\
\hline $501-1000$ & Corrosive & Extremely corrosive \\
\hline $0-500$ & Very corrosive & Extremely corrosive \\
\hline
\end{tabular}

Table 3: A comparison between the British Standard BS-1377 for evaluating corrosion and the expected degree of corrosivity in the study area (Obama - Kolo creek pipeline route)

\begin{tabular}{|l|l|l|}
\hline \multicolumn{1}{|c|}{$\begin{array}{c}\text { Soil Resistivity }(\Omega \mathrm{m}) \% \text { of } \\
\text { measurement points }\end{array}$} & $\begin{array}{l}\text { Obama - Kolo creek } \\
\text { Pipeline route }\end{array}$ & Soil Corrosivity \\
\hline Above 100 & 2.5 & Mot corrosive \\
\hline $50-100$ & 25.0 & Moderately corrosive \\
\hline $30-50$ & 36.5 & Very corrosive \\
\hline $10-30$ & 34.0 & Severe \\
\hline Below 10 & 2.0 & \\
\hline
\end{tabular}




\section{CONCLUSIONS}

The corrosion that occurs in metal structures when buried in the ground is a major concern to engineers responsible for projects that require their design. All of the investigations collected in this research on the assessment of soil corrosivity along Obama - Kolo creek pipeline have been classified according to the vertical electrical sounding conducted in the area. The data was interpreted using a 1D inversion technique software (IP12Win). Model resistivity values were classified in terms of the degree of corrosivity. Generally, the sub-soil condition along the pipeline route is highly aggressive in the entire areas due to local conditions prevailing geology at the measuring stations. It must be noted that piping structures installed along the proposed pipeline routes would be subjected corrosion. The effect is expected to be more severe in areas dominated by mangrove plants because of the influence of saline water. Based on the corrosivity along the pipeline route investigated, appropriate cathodic protection methods are recommended.

\section{REFERENCES}

[1] Amechi, B.U., Tamunobereton-ari, I., \& Womuru, E. N. (2018) Application of Earth Resistivity Measurement in the North Eastern Rivers State. (a Geoelectric based study). J. of scientific and engineering research, 5(2) 18 - 24

[2] Doust, H. \& Omatsola, E. (1990). Niger Delta in divergent/passive margin basins. In J.D. Edwards and P.A. Santogrossi (eds). American Association of Petroleum Geology. Memoir 48, pp. 201-238.

[3] Ekine, A.S. \& Emujakporue, G.O (2010) Investigation of corrosion of buried oil pipeline by electrical geophysical method. J. of Appl. Sciences an environmental management. 14, 63 - 65.

[4] Hazel, J.R.T. Geological Society of Nigeria (GSN) Reports (1985). Hydrogeology of Eastern Nigeria. pp 55.

[5] Hussein E. \& Tarig E. (2014). Evaluation of subsoil corrosivity condition around Baracaia area using the electrical resistivity method - a case study from the muglad basin, Southwestern sudan. Journal ofs Earth Science and Engineering 4, 326-330.

[6] Ofodile, M.E. (1984). An approach to groundwater study and development in Nigeria. Mecon Services Ltd. Nig.

[7] Oyedele K. F., Meshida E., \& Obidike, C.C (2012) Assessment of Coastal Soil Corrosivity Using Resistivity Tomography at Lekki. Lagos, Nigeria. International Journal of Science and Advanced Technology (ISSN 2221-8386) Volume 2 No 6 June 2012.

[8] Oyinkanola, L.O.A, Fajemeroye, F.A, Tijani, B.O and Oke, D.A (2016) correlation between soil electrical resistivity and metal corrosion based on soil types for structural designs. Scientific Research Journal. Vol. IV, 2201 $-2296$

[9] Parasnis, D. S. 1979, Principle of Applied Geophysics. Chapman and Hall - John Wiley and Sons, New York.

[10] Reijers T. J. A., Petter, S. W. \& Nwajide C. S. (1996). The Niger Delta Basin. In T.J.A. Reijers (Eds.), Selected Chapters on Geology: Sedimentary Geology and Sequence Stratigraphy of Anambra basin (pp. 103-117). Warri, Nigeria: SPDC Corporate Reprographic Services.

[11] Telford, W.M., Geldart, L.P, Sherift, R.E \& Keys, D.A., 1976. Applied Geophysics. Cambridge University Press, Landon. 